\title{
Popular religion and sustainability: enhancing synergies within a Biosphere Reserve
}

\author{
Abraham Paulsen, Danilo Petrovich \& Andrés Moreira-Muñoz \\ Keywords: vernacular religion, Multi-Internationally Designated Areas, natural sanctuaries, Chile
}

\section{Abstract}

The potential benefits of integrating vernacular religious beliefs into biodiversity conservation and sustainability actions have been emphasized widely, while specific examples and the synergies between religious communities and conservationists in particular spaces deserve more attention. The manifestations of vernacular religions in territories devoted to sustainability, such as Biosphere Reserves (BRs), are a particularly rich area for study. While La Campana-Peñuelas BR has long been recognized as a territory where local religion is an important feature, greater awareness of this and of the potential link to sustainability actions is still lacking, as is awareness of the potential of the BR to become a Multi-Internationally Designated Area. Here we report on the diversity of popular religious activities within the BR. Possible synergies between popular religion and sustainability are based on the strong organizational capacities of local communities, and on an ethical vision of social justice that encompasses both human relations and attitudes towards the non-human beings within the biosphere.

\section{Profile}

Protected area

La Campana-Peñuelas

\section{Biosphere Reserve}

Mountain range

Andes, Chile

\section{Introduction}

There is overwhelming scientific evidence that human actions at the global scale are destabilizing the biosphere, putting all life on Earth in danger (Steffen et al. 2015). The urgent need for actions that promote a better harmonization of human activities within the biosphere is evident. The laissez-faire attitude of much of global society, however, pushing humanity towards over-consumption, pollution and environmental crisis, is marked by a loss of a sense of empathy and responsibility towards others, humans and non-humans.

Actions that aim to regenerate territories which are already environmentally impoverished require a robust attitude in the face of social injustice and common unsustainable practices. This requires a new environmental ethic, and this is where religion comes into play: "Religion functions as both a source and legitimator of moral values, arising from a faith ethos or culture, which construct the duties, joys, and responsibilities of how people order their lives and their relationships with each other, with the Divine, and with the natural world' (Northcott 1996, as cited by Mcleod \& Palmer 2015).

Biosphere Reserves (BRs), recognized as territories for promoting the transition towards sustainability, are areas in which religion can help build an ethical basis for action. While interest in biocultural diversity in BRs and actions to promote it are increasing (MoreiraMuñoz et al. in press), the link between popular religion and sustainability has drawn little attention. Here, we report briefly on popular religious practices within La Campana-Peñuelas BR and present some reflections on how to promote sustainable synergies in BRs in their transition towards sustainability.

\section{La Campana-Peñuelas, a Biosphere Reserve under threat}

Intense conflicts arise in La Campana-Peñuelas due to its location within the two most populated regions in Chile: Santiago and Valparaíso. Direct threats to the BR include urban sprawl, agriculture and agrochemical pollution, wildfires, environmental injustices, and conflicts over water supplies (Salazar et al. 2015); and in general a lack of awareness among local people of the environmental values of the BR. In recent years, threats to the BR have been intensified by the arbitrary installation of massive overhead power lines. In addition, a fossil-fuel thermal power station has been proposed, generating popular demonstrations against it (Figure 1). To the north of the BR, along the Aconcagua and La Ligua rivers, conflicts over water are increasing, with agribusiness affecting communities' local water provision (Panez-Pinto et al. 2018) (Figure 1). The north-west of the BR has become a so called sacrifice zone (Figure 1). Here, Quintero-Puchuncaví industrial complex is contaminating the surrounding environment in its entirety - water, soil, atmosphere and people.

\section{Biosphere Reserves as spaces for conserva- tion, sustainability and belief}

Within the context of La Campana-Peñuelas BR as described above, all aspects of sustainability within and around the BR need to be enhanced. While there have been some efforts towards ecosystem restoration (Carvajal et al. 2018), ethical and spiritual aspects have still not received sufficient attention. This is currently 


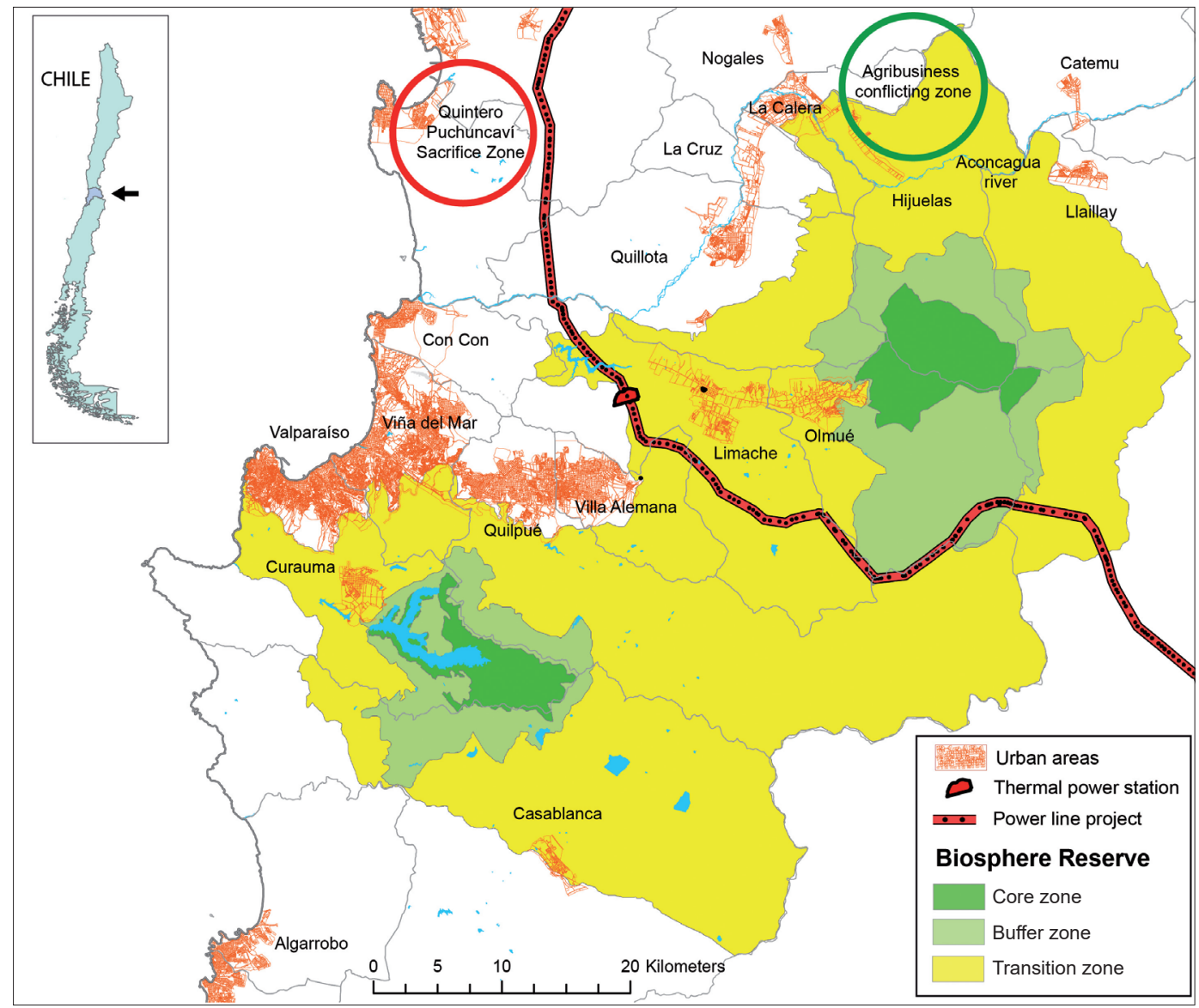

Figure 1 - Increasing threats within and around La Campana-Peñuelas BR: current fragmentation of the BR due to the power line, and location of the possible fossil-fuel thermal power station (map A. Moreira-Muñoz).

one of the main failings of the BR, which is related to the weak presence of the MAB Programme in Chile (Moreira-Muñoz et al. in press).

Partnerships between religious communities and those responsible for sustainability actions are desirable (Mcleod \& Palmer 2015). Within the BR, such partnerships would enhance an ethic that respects life. Popular religious activities are a characteristic of the $\mathrm{BR}$, as has already been recognized in early surveys (e.g. Elórtegui \& Moreira-Muñoz 2002). A more detailed survey of the current popular religious practices within and around the BR are summarized in Table 1.
Popular events include a range of activities, from the most private ones, inside individual homes (popular singers for saints' days and wakes), to the most massive: Lo Vásquez Sanctuary, which attracts thousands of pilgrims. Not all these events have the potential to create synergies with conservation actions, which is a real challenge: for instance, the Lo Vásquez pilgrimage leaves behind tons of rubbish. This opens an opportunity to work with local environmental groups.

The Niño Dios de Las Palmas is associated with a pilgrim route that goes through the heart of the BR, La Campana National Park. People come to visit the

Table 1 - Popular religious practices within and around La Campana-Peñuelas BR.

\begin{tabular}{|l|l|l|l|}
\hline $\begin{array}{l}\text { Popular religious sites } \\
\text { or events }\end{array}$ & Location & Date or season & Main features \\
\hline $\begin{array}{l}\text { Religious Sanctuary (in- } \\
\text { cluding pilgrim routes) }\end{array}$ & $\begin{array}{l}\text { Virgen de las 40 horas (Figures 2, 3: } \\
\text { Star 1) }\end{array}$ & Last Sunday in February & attracts hundreds of people each February \\
\cline { 2 - 4 } & $\begin{array}{l}\text { Niño Dios de Las Palmas (Figure 3: } \\
\text { Star 2) }\end{array}$ & Easter and Christmas & $\begin{array}{l}\text { relatively small, attracting pilgrims from } \\
\text { the rural areas }\end{array}$ \\
\cline { 2 - 4 } & Lo Vásquez (Figure 3: Star 3) & $\begin{array}{l}\text { Feast of the Immaculate } \\
\text { Conception (8 December) }\end{array}$ & $\begin{array}{l}\text { attracts around 1 million people each } \\
\text { year }\end{array}$ \\
\hline \multirow{2}{*}{ Bailes chinos } & Throughout the BR (Figures 2, 3) & All year round & $\begin{array}{l}\text { Traditional religious dances, recog- } \\
\text { nized as Intangible Cultural Heritage of } \\
\text { Humanity }\end{array}$ \\
\hline \multirow{2}{*}{ Quasimodo procession } & $\begin{array}{l}\text { Quillota, Valparaíso, San Felipe, } \\
\text { Limache, Reñaca Alto (Figure 3) }\end{array}$ & $\begin{array}{l}\text { 15t Sunday after Easter } \\
\text { people on horseback. }\end{array}$ \\
\hline $\begin{array}{l}\text { Canto a lo Divino (popu- } \\
\text { lar singers) }\end{array}$ & Throughout the BR (Figure 3) & All year round & $\begin{array}{l}\text { Traditional songs, accompanied by a } \\
\text { guitar, sung on feast days and at wakes }\end{array}$ \\
\hline
\end{tabular}



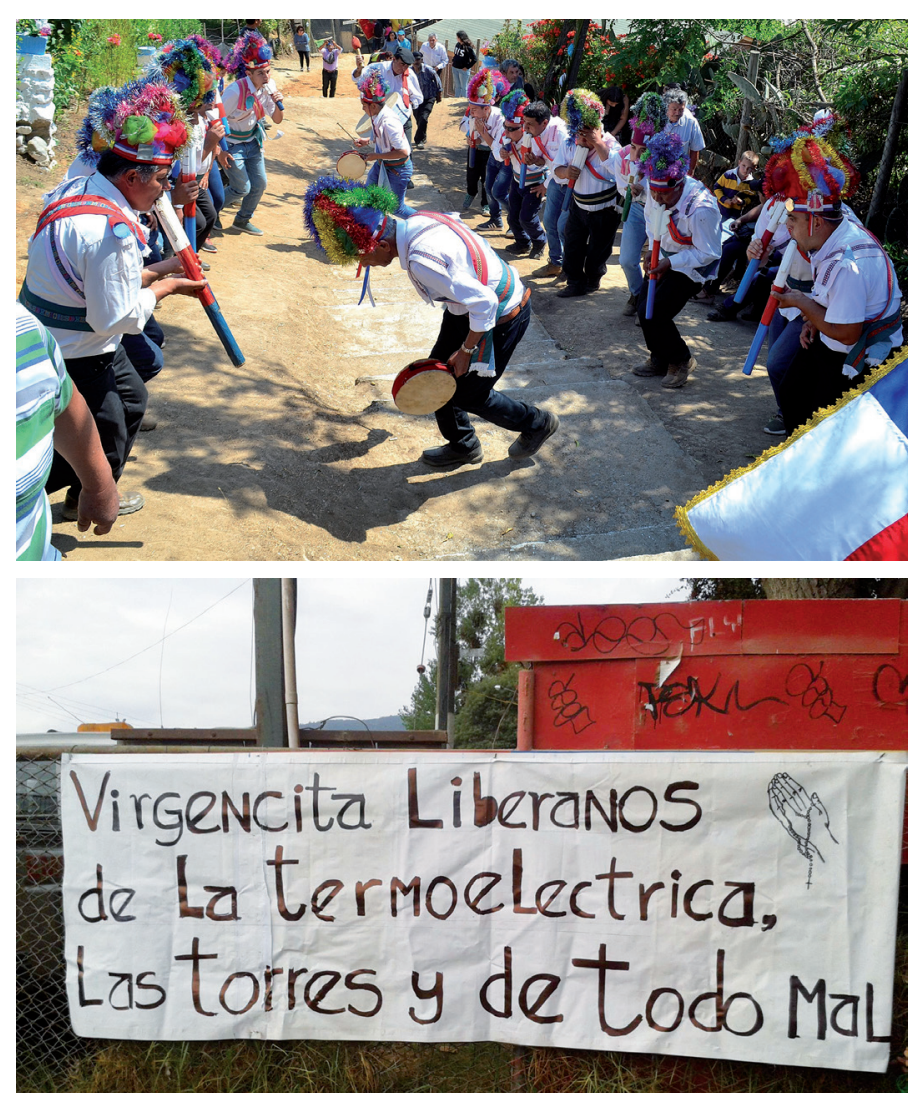

Figure 2 - Vernacular religious practices within and around La CampanaPeñuelas BR: Top: Baile chino de Cai Cai in Limache (C) Gastón Luna; Bottom: "Virgin save us from the thermal power station, the pylons and all evil". Photo credits. (C) Libres de Alta Tensión environmental movement.

statue of the Christ child housed in the little church in Las Palmas. The pilgrimage route to las Palmas crosses the NP, creating another type of connection with nature through the pilgrimage under the sclerophyllous forests. This pilgrimage recalls one that no longer exists - the procession organized by the Congregation of the Sacred Heart at the end of the $19^{\text {th }}$ century. The old pilgrimage route passes under ancient belloto forests (Beilschmiedia miersii), opening the imagination to a very deep connection with the natural environment.

Bailes Chinos (local traditional dances), for example those that call for rain, have a spiritual connection to the environment. They usually occur in local rural communities where respect for the Earth and its fruits is the norm. Ancient, traditional, handicrafts also reflect links to the environment: there are families, such as the Ponce family at Quebrada de Alvarado, who still make flutes for the dances, using local woods. Another emergent link between religion and the environment are the prayers of the 40 Horas ( 40 hours) celebration. An environmental aspect has recently been added to the traditional religious content, and prayers nowadays call for the dissolution of environmental threats (Figures 2 Bottom).

Material and immaterial heritage may coincide (Manríquez et al. 2019): there are locations that are recognized both as religious sanctuaries and as natu- ral ones. And indeed, popular religion manifests itself spatially within the BR: most of the Bailes Chinos are located along Olmué-Limache axis (Figure 3) or in the north, in the valley of the Aconcagua river. Interestingly, while isolated from the rest, the Bailes Chinos in Quintero-Puchuncaví show spiritual similarities to other practices in the region. These dances have their roots in colonial times, in small communities in the North of Chile (Contreras \& González 2012), but they are now a well-established tradition in Chilean society more widely and are still alive in these times of globalization (UNESCO 2004).

\section{Possible synergies between popular reli- gion and sustainability}

The overlaying of priority conservation sites and religious practices has been reported at different scales, from the global to the regional (Negi 2005; Tatay-Nieto \& Muñoz-Igualada 2019). Features of popular old traditional religious manifestations in Spain (pilgrimage routes, shrines, hermitages and monasteries) coincide geographically with the Natura 2000 network, which protects threatened species and habitats (Tatay-Nieto \& Muñoz-Igualada 2019). In La Campana-Peñuelas BR similarly, the natural heritage and religious / cultural traditions occupy the same spaces.

It is important to recognize that ancient religious practices pre-date contemporary conservation discourses and initiatives (Adler 2006; Gavilán Vega \& Carrasco 2009; Berry 2015; Frascaroli 2013), and that religious ethics have inspired great names in the environmental movement, such as the American conservationist John Muir (Powell 2019). There is evidence that scientists and conservationists are ultimately motivated by mystical / spiritual experiences in nature which build on formal religion (Macleod \& Palmer 2015).

In specific territories where a greater harmony between human and non-human communities has long existed, the spiritual, sacred, meanings of certain plants and animals have been important in the development of a sacred geography (Posey 1999; Snodgrass \& Tiedje 2008; Pungetti et al. 2012; Grabauskas 2016; Tatay-Nieto \& Muñoz-Igualada 2018). La CampanaPeñuelas BR, in combination with the World Heritage Site Valparaíso and the Bailes chinos (which are recognized as Intangible Cultural Heritage of Humanity (UNESCO 2014; Manríquez et al. 2019), is a MultiInternationally Designated Area (MIDA) (Schaaf \& Clamote Rodrigues 2016). The potential of BRs to enhance social-ecological harmony has already been proposed by Moreira-Muñoz et al. (in press). This can act in synergy with other efforts, such as Intergenerational Practice (IP), which has been proposed as one way of enhancing participation within BRs, by integrating young people and elderly women (Mitrofanenko et al. 2018). Today, the presence of religious groups with an ethic of responsibility and love for other humans and non-humans gives hope for this territory in particular, 


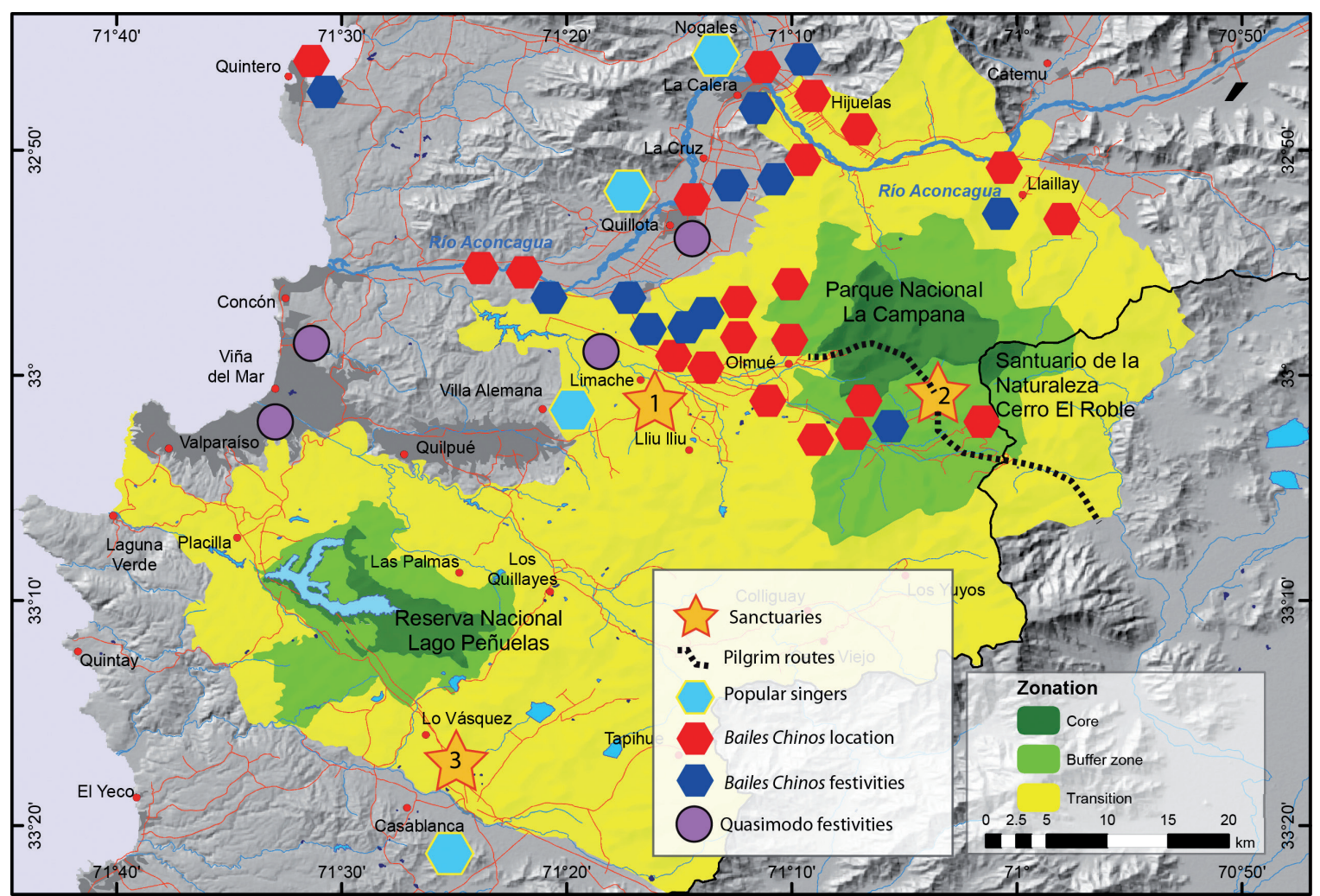

Figure 3 - Locations of vernacular religious practices within and around La Campana-Peñuelas BR (map by D. Petrovich and A. Moreira-Muñoz).

and provides a possible way forward for the rest of Chilean society, which is generally alienated from nature and spiritual connection.

\section{Acknowledgements}

This report includes results obtained by Fondecyt project \# 11150541 (2016-2018) and is part of the Conicyt-PIA Anillos SOC180040 project (2018-2021).

\section{References}

Adler, J. 2006. Cultivating Wilderness: Environmentalism and Legacies of Early Christian Ascetism. Society for Comparative Study of Society and History 48: 4-37.

Berry, E. 2015. Devoted to Nature. The Religious Roots of American Environmentalism. Oakland.

Carvajal, F., M. Palape, C.Hernández \& A. MoreiraMuñoz 2018. Cushion plants of the Andes an inspiration for the implementation of micro biodiversity hotspots. Proceedings Conference Mountains 2018, Nova Friburgo, Brazil, 10-14 Dezember 2018.

Contreras Mühlenbrock, R. \& D. González Hernández 2012. Será Hasta la Vuelta del Año. Bailes Chinos, Festividades y Religiosidad Popular del Norte Chico. Consejo Nacional de la Cultura y las Artes, Santiago. [In Spanish]

Elórtegui, S. \& A. Moreira-Muñoz (eds.) 2002. Parque Nacional La Campana: Origen de una Reserva de la
Biosfera en Chile central. Taller La Era, Viña del Mar. [In Spanish]

Frascaroli, F. 2013. Catholicism and Conservation: The Potential of Sacred Natural Sites for Biodiversity Management in Central Italy. Human Ecology 41(4): 587-601.

Gavilán Vega, V. \& A.M. Carrasco 2009. Festividades Andinas y Religiosidad en el Norte Chileno. Chungará, Revista de Antropología Chilena 41(1): 101112. [In Spanish]

Grabauskas, E. 2016. Tree Worship: Accidental Conservation of Biodiversity through the Protection of Biodivinity. Denison Journal of Religion 15, 5. Available at: h5p://digitalcommons.denison.edu/religion/ vol15/iss $1 / 5$

Manríquez, H., P. Mansilla, R. Figueroa-Sterquel \& A. Moreira-Muñoz 2019. Geodiversity meets Biodiversity: a landscape approach for biogeocultural conservation and governance in Mediterranean central Chile. eco.mont 11(1): 43-48.

McLeod, E. \& M. Palmer 2015. Why Conservation Needs Religion. Coastal Management 43: 238-252.

Mitrofanenko T., J. Snajdr, A. Muhar, M. Penker \& E. Schauppenlehner-Kloyber 2018. Biosphere Reserve for All: Potentials for Involving Underrepresented Age Groups in the Development of a Biosphere Reserve through Intergenerational Practice. Environmental Management 62: 429-445.

Moreira-Muñoz, A., F. Carvajal, S. Elórtegui \& R. Rozzi (in press). The Chilean Biosphere Reserves net- 
work as a model for sustainability?: challenges towards regenerative development, education, biocultural ethics and eco-social peace. In: Reed, M. \& M. Price, UNESCO Biosphere Reserves: Supporting Biocultural Diversity, Sustainability and Society.

Negi, C.S. 2005. Religion and biodiversity conservation: not a mere analogy. International Journal of Biodiversity Science and Management 1: 85-96

Panez-Pinto, A., P. Mansilla \& A. Moreira-Muñoz 2019. Agua, tierra y fractura socio-metabólica del agronegocio: Actividad frutícola en Petorca, Chile. Bitácora Urbano Territorial 28(3): 156-160 http:/ /www. bitacora.unal.edu.co/

Posey, D.A. 1999. Culture and Nature of Biodiversity. Introduction: Culture and Nature - The inextricable link. https://doi.org/10.3362/9781780445434.001

Powell, R.C. 2019. John Muir and the Botanical Oversoul. Religions 10, 92. doi:10.3390/rel10020092

Pungetti, G., P. Hughes \& O. Rackham 2012. Ecological and spiritual values of landscape: a reciprocal heritage and custody. In: Pungetti, G., G. Oviedo \& D. Hooke, Sacred Species and Sites. Advances in Biocultural Conservation: 65-82.

Salazar, A., A. Moreira-Muñoz \& C. del Río 2015. La Campana-Peñuelas Biosphere Reserve in Central Chile: threats and challenges in a peri-urban transition zone. eco.mont 7(1): 66-71. doi:10.1553/eco.mont-7$1 \mathrm{~s} 66$.

Schaaf, T. \& D. Clamote Rodrigues 2016. Managing MIDAs: Harmonising the management of Multi-Internationally Designated Areas: Ramsar Sites, World Heritage sites, Biosphere Reserves and UNESCO Global Geoparks. Gland: IUCN.

Snodgrass, J.G. \& K. Tiedje 2008. Indigenous nature reverence and conservation. Seven ways of transcending an unnecessary dichotomy. Journal for the Study of Religion, Nature, and Culture 2(1): 6-29.
Steffen, W., K. Richardson, J. Rockström, S.E. Cornell, I. Fetzer, E.M. Bennett, R. Biggs, S.R. Carpenter, W. de Vries, C.A. de Wit, C. Folke, D. Gerten, J. Heinke, G.M. Mace, L.M. Persson, V. Ramanathan, B. Reyers \& S. Sörlin 2015. Planetary boundaries: guiding human development on a changing planet. Science 347: 1259855

Tatay-Nieto, J. \& J. Muñoz-Igualada 2019. Popular Religion, Sacred Natural Sites, and "Marian Verdant Advocations" in Spain. Religions 10: 1-15.

UNESCO 2014. Baile Chino. Available at: https:// ich.unesco.org/en/RL/baile-chino-00988 (accessed: 05/03/2019)

\section{Authors}

\section{Abraham Paulsen}

Associate Professor in Human Geography, currently working the geography of religions. Instituto de Geografía, Pontificia Universidad Católica de Chile, Av. Vicuña Mackenna 4860, Macul, Santiago. E-mail: apaulsen@uc.cl

\section{Danilo Petrovich}

Anthropologist, currently working on the documentation of immaterial heritage. Museo Campesino en Movimiento (MUCAM); https://www.mucam.cl/ E-mail: petrodanilovich@gmail.com

\section{Andrés Moreira-Muñoz}

Full Professor in Biogeography and Sustainability Science, with research interests in conservation biogeography and regenerative systems. www.biogeolab.org. Instituto de Geografía, Pontificia Universidad Católica de Valparaíso, Avenida Brasil 2241, Valparaíso, Chile. E-mail: andres.moreira@pucv.cl 